\title{
Zjawisko sponsoringu młodych kobiet na łamach czasopism społeczno-politycznych
}

Wśród wielu zjawisk z zakresu patologii społecznej niezmiennie wymienia się prostytucję, co na ogół oznacza wadliwą socjalizację leżącą u podłoża tego typu zachowań. Wiadomo, że za proces wychowania młodego pokolenia odpowiada przede wszystkim rodzina, w niej więc poszukuje się źródeł jego zaburzeń, ujawniających się różnego typu nieprzystosowaniem społecznym jednostki. Do nich bezsprzecznie należy występujący obecnie w naszym kraju na coraz większą skalę sponsoring. Szczególnie niepokojący z pedagogicznego punktu widzenia jest fakt, że dotyczy on młodych kobiet.

Zjawisko sponsoringu, wg Zbigniewa Izdebskiego, szerzy się przede wszystkim w środowisku studenckim. Młode osoby dążą do zapewnienia sobie dobrych warunków materialnych, umożliwiających edukację w uczelniach wyższych. Sponsor ponosi wysokie koszty związane z zapewnieniem standardu życia swojego partnera lub partnerki, m.in. opłaca mieszkanie i czesne za studia, w formie prezentów kupuje modną odzież bądź biżuterię ${ }^{1}$. Termin sponsoring pojawił się dopiero w ostatnich latach, wielu - szczególnie młodym osobom - wydaje się bardziej atrakcyjny niż prostytucja, łatwiej jest go też zaakceptować.

Przełom XX i XXI w. przyniósł zmiany w dziedzinie seksualności człowieka, co Brian McNair nazwał „kulturą obnażania się”. Jest to konsekwencja nasycenia kultury masowej oraz sztuk wizualnych symbolami seksualnymi². Dehumanizacja

* Prof. dr hab., Zakład Edukacji Ustawicznej, Instytut Nauk Pedagogicznych, Wydział Historyczno-Pedagogiczny, Uniwersytet Opolski, 45-052 Opole, ul. Oleska 48.

1 R. Gardian, Zjawisko sponsoringu jako forma prostytucji kobiecej, Kraków 2007, s. 51; K. S tu ż y n a, Przerwać milczenie, „Głos Nauczycielski” 2003, nr 33, s. 1.

${ }^{2}$ B. M c Na i r, Seks, demokratyzacja poglądów czyli media. Kultura obnażania się, Warszawa 2004, s. 8 i nast. 
seksu przyczynia się do instrumentalnego traktowania własnego ciała, tym samym może skłaniać młode osoby do prostytuowania się ${ }^{3}$.

Prawidłowy i społecznie akceptowany stosunek do ciała ludzkiego powinien się kształtować w naturalnym środowisku, bowiem każda rodzina wywiera istotny wpływ na budowanie określonego systemu wartości już od najmłodszych lat życia dziecka, które wzrastając w nim poznaje, czym jest dobro i zło, na podstawie obserwacji zachowania dorosłych dowiaduje się, co w życiu jest ważne, jakich właściwych wyborów należy dokonywać. Preferowane w rodzinie wartości i normy moralne są zdeterminowane więziami łączącymi członków rodziny, a należą do nich m.in. więzi intymne i prywatne. Pierwsze z nich przyczyniają się do naturalnej ochrony płciowości, są więc związane z poczuciem wstydu, chroniąc sferę intymną życia człowieka. Natomiast drugie, czyli więzi prywatne mają zapewniać ochronę tego, co nie nadaje się do upublicznienia ${ }^{4}$.

Intymność i prywatność rodziny jako wspólnoty osób chronią wartości i normy moralne nabywane $\mathrm{w}$ procesie wychowania moralnego. Jego istotą są takie oddziaływania wychowawcze na osobowość młodej jednostki, aby w ich wyniku umiała odróżnić dobro od zła, przyjęła i zaakceptowała określone normy postępowania. Nie zawsze jednak daje ono spodziewane i pożądane efekty 5 .

Nieprawidłowości występujące w rodzinie, zaniedbania wychowawcze rodziców powodują, że młode pokolenie niejednokrotnie odrzuca tradycyjne wartości i normy postępowania. Doświadczanie przemocy, brak więzi emocjonalnych i poczucia bezpieczeństwa w rodzinie mogą przyczynić się do podjęcia decyzji o sprzedawaniu własnego ciała, czego rezultatem może być również zjawisko sponsoringu, które - według socjologów - jest quasi prostytucją, ograniczoną do więzi z jednym stałym partnerem, $z$ większą możliwością dyktowania warunków ${ }^{6}$. J. Wódz natomiast uważa, że jest to „ukryta forma prostytucji, w której kobieta ma możliwość wyboru partnera"?.

Przemiany ustrojowo-społeczne, dokonujące się w naszym kraju, przyczyniły się do relatywizacji norm społecznych, kryzysu wartości, a w nowych warunkach tradycyjne środowiska wychowawcze, tj. rodzina i szkoła, niejednokrotnie okazywały się bezradne. W następstwie obniżania się ich kondycji wychowawczej nie tylko pojawiły się problemy tożsamościowe młodego pokolenia, lecz także - związane z kształtowaniem się systemu wartości. Te zagadnienia stanowią przedmiot dociekań teoretyków i praktyków oraz są obiektem naukowo-badawczej eksploracji. Jednak szybkość, z jaką reagują media na zjawiska dziejące się w obecnej rzeczywistości sprawia, że bez względu na to, czy te przekazy mają postać drukowaną, czy elektroniczną, są ważnym i aktualnym przekaźnikiem współczesnych problemów społecznych. Szczególnie cenne są one dla badacza - historyka wy-

${ }^{3}$ Prostytucja jako problem społeczny, moralny i zdrowotny, red. M. Jędrzejko, PultuskWarszawa 2006, s. 20.

${ }^{4}$ A. S z ołt y s e k, Filozofia wychowania moralnego, Kraków 2009, s. 240.

${ }^{5}$ M. Ło b o c ki, Wychowanie moralne w zarysie, Kraków 2002, s. 181 i nast.

${ }^{6} \mathrm{~K}$. Ch a rk ow ska, Zjawisko prostytucji w doświadczeniach prostytuujących się kobiet, Kraków 2010, s. 30.

7 M. G le ń, Studentka szuka sponsora, „Eurostudent” 2004, nr 96, s. 12. 
chowania, poszukującego materiałów do poznania zjawisk, które w określonym czasie mają wpływ na przebieg procesu wychowania zarówno młodych, jak i dorosłych osób.

Nowe zjawiska patologiczne w życiu codziennym, mające miejsce w naszym społeczeństwie, w tym również analizowany w niniejszych rozważaniach sponsoring, znajdują bezpośrednie odzwierciedlenie w czasopiśmiennictwie. Analizując zawartość treści artykułów w nich publikowanych, zmierzałam do uzyskania odpowiedzi na następujące pytania: jakie czynniki determinują zjawisko sponsoringu młodych kobiet; jaka jest reakcja społeczna wobec niego; jakie zagrożenia dla osobistego rozwoju młodych kobiet są z nim związane? Analizie zostały poddane artykuły zamieszczone w czasopismach społeczno-politycznych, takich jak m.in.: „Newsweek”, „Polityka” i „Wprost”, zarówno ich wydania internetowe, jak i tradycyjne oraz pisma kierowane do kobiet i studentów.

Sponsoring jest zjawiskiem dość szeroko znanym wśród osób studiujących. Młodzi, ambitni, uczący się na wyższych uczelniach wiedzą o nim nie tylko z czasopism, lecz także z własnych doświadczeń, gdyż coraz więcej studentek decyduje się na kontakty ze sponsorem. Seksuolog Z. Izdebski tłumaczy: „być może jest to wynik tego, że generalnie coraz więcej osób w Polsce kształci się na wyższych uczelniach, ale jednocześnie jeszcze nigdy w takim wysokim procencie osoby prostytuujące się nie mówiły, że motywem prostytucji są cele o charakterze edukacyjnym"8.

Sponsoring wśród studentek często przebiega według określonego scenariusza: dziewczyna przyjeżdża na studia do dużego miasta z małej miejscowości, jej rodziców stać jedynie na opłacenie akademika i zapewnienie córce skromnego utrzymania. Ona widzi jednak, że można żyć inaczej, bowiem jej koleżanki mają firmowe ubrania, bawią się w modnych klubach, a ona od tego stylu życia odstaje. Szuka zatem sponsora. To tylko jeden ze scenariuszy, bowiem sponsoring uprawiają również studentki z rodzin zapewniających im przyzwoite warunki studiowania. Z tej formy zarabiania korzystają też licealistki, kobiety kończące studia i matki samotnie wychowujące dzieci. Sponsorów miewają również mężczyźni, którzy za seks pozwalają utrzymywać się kobietom bądź też innym mężczyznom, nawet, jeśli nie są gejami.

Motywem, który skłania do podjęcia tego zajęcia jest szybka i łatwa droga do zdobycia pieniędzy oraz poprawienia statusu ekonomicznego i podwyższenia standardu życia, którego nie mogą zagwarantować rodzice. O dobrze płatną pracę w ośrodkach akademickich nie jest łatwo, stypendia nie są zbyt wysokie, a za utrzymanie i studiowanie trzeba płacić. Potrzebny jest zatem regularny przypływ gotówki, którą może zagwarantować bogaty sponsor. "Nie chodzi o to, co robię z nim w łóżku, tylko o to, dlaczego muszę to robić, żeby studiować - mówi Marta, studentka pedagogiki. Jest ambitna i nie ma złudzeń. Wie, że studia kosztują. $\mathrm{Na}$ rodziców nie może liczyć, więc znalazła sponsora, jak wiele dziewczyn na uczelni". Marta to efektowna, szczupła dziewczyna, zawsze w starannym makijażu, na zajęcia wchodzi spóźniona, pobrzękując biżuterią i wymachując torebką od Luisa

${ }^{8}$ P. R u s a k, Dają ciała, by studiować, „Dlaczego” 2007, nr 87. 
Vuittona. Kiedy trzy lata temu dziewczyna z Kieleckiego rozpoczynała studia i życie $w$ wielkim mieście, modelkę przypominała tylko $z$ figury. Ubrania ze Stadionu X-lecia i podróbka torby znanej firmy bezlitośnie obnażały aspiracje panny z prowincji. Pół roku później Marta paradowała już w ciuchach, o jakich doktorantki i profesorki mogły tylko marzyć. Odkąd poznała Łukasza, 54-letniego specjalistę w jednej z firm farmaceutycznych, męża i ojca, jej życie w stolicy całkowicie się odmieniło?.

Kobiet szukających sponsora nie można znaleźć w agencjach towarzyskich, nie zaczepiają one potencjalnych klientów na ulicach i nie stoją przy drogach. Najczęściej zawierają znajomość poprzez portale internetowe, ale też poznają ich podczas spotkań towarzyskich, wystaw, wernisaży. Młode dziewczyny są inteligentne, znają języki obce, a zdobyte od mężczyzn środki finansowe pozwalają im łatwiej żyć. Przykładem jest historia Marii, której rodzice „są dobrze sytuowani - ojciec lekarz i matka urzędniczka na kierowniczym stanowisku. Wyznają jednak zasadę, żeby uczyć dzieci szacunku do pracy i pieniędzy. Sami na studia przyjechali z małych miejscowości. Doświadczyli awansu społecznego i ekonomicznego. W rolniczej rodzinie ojca Marii panował kult ziemi i pracy. Dziadek zawsze powtarzał, że tylko ciężką pracą można dojść do celu, że praca kształtuje charakter. W domu ani Marii, ani jej starszemu o dwa lata bratu niczego nie brakowało, ale nigdy nie dostawali pieniędzy na super ciuchy, kieszonkowe też było raczej skromne. Przynajmniej miesiąc wakacji spędzali pracując. Rodzice zapewniali, że wyposażą swoje dzieci na przyszłość, najpierw jednak muszą skończyć studia i nauczyć się pracować. - „Nienawidzę tych archaicznych poglądów ojca - mówi Maria. Harówka niczego nie kształtuje, może poza garbem. To już nie są te czasy. Oni wyobrażają sobie, że mogę studiować dziennie, mieć dobre wyniki i jeszcze pracować w jakimś McDonaldzie albo roznosząc ulotki? Bzdura"10.

Dziewczyny mające sponsora nie rzucają się w oczy agresywnym makijażem, czasami mają wręcz twarz niewiniątka. „Wykładowcy na pedagogice w prywatnej uczelni lubią takie studentki - skromne, pilne, bez stringów wystających znad kusych biodrówek. Tylko nieliczni wiedzą, że mają sponsora. Ania od dwóch lat robi wszystko, żeby to ukryć. O tym, że czynsz za mieszkanie w Śródmieściu, rachunki za telefon i Internet oraz czesne płaci sponsor, nie wiedzą nawet najlepsze koleżanki. Mają myśleć, że utrzymują ją rodzice, choć w małej wsi na Lubelszczyźnie mało kogo stać na wysyłanie choćby kilkuset złotych miesięcznie, a co dopiero kilku tysięcy. Koleżanki myślą, że Ania dorabia pisaniem prac magisterskich"11.

Seks w zamian za mieszkanie i utrzymanie się na studiach to jedna z popularniejszych form studenckiej prostytucji. Studentki traktują to jako pracę, a zarazem inwestycję w siebie. Rodzicom nagłe pojawienie się drogich ubrań, perfum, kosmetyków tłumaczą podjęciem dorywczej pracy w ambasadzie lub opiekunki do dziecka w bogatych rodzinach.

\footnotetext{
9 b.a., Studentka dla sponsora, „Wprost”, 7.02.2010, s. 27.

10 http://www.estudent.pl/post/wyznania-utrzymanki [data dostępu: 20.06.2011].

11 Tamże.
} 
Młodzi ludzie zdają sobie sprawę, że obecnie nie tylko dyplom, ale również brak drogich oraz ekskluzywnych rzeczy może utrudnić osiągnięcie sukcesu zawodowego i towarzyskiego.

Przeciętna dziewczyna, zwłaszcza przyjeżdżająca na studia ze wsi lub małego miasteczka, może sobie pozwolić jedynie na standard podstawowy. Jeśli studiuje w uczelni prywatnej, musi zapłacić czesne, niejednokrotnie przekraczające możliwości finansowe rodziców. „Płatne studia, mówi Roksana dorabiająca w agencji towarzyskiej, to największy napęd prostytucji. Wolę w końcu ten burdel niż harówkę w jakimś McDonaldzie"12.

Również dziewczyny wywodzące się z domów, które mogą zapłacić za czesne mając zapewnione przez rodziców przyzwoite utrzymanie, szukają jednak sponsorów. Chcą mieć możliwość zakupu markowej odzieży, zagranicznych wyjazdów do egzotycznych krajów, książek, aby nie musieć spędzać czasu w bibliotekach. To pewnie pierwszy w historii tego zajęcia przypadek, że kupuje się za nie książki. Ale nie tylko z pragnienia luksusu dziewczyny chcą sponsora. Pragną oderwać się od szarzyzny życia, przeżyć przygodę, a także znaleźć bogatego męża ${ }^{13}$.

Psycholodzy, analizując to zjawisko, szukają jego przyczyn głównie w rodzinie, wskazując, że młode kobiety zarabiające w ten sposób mają zaburzony system wartości, brakuje im zainteresowania i miłości ze strony najbliższych osób czyli rodziców. „Niewątpliwie rodzice sponsorowanych dziewczyn mogą być dobrzy i kochający. Być może ciężko harują, by związać koniec z końcem i nie mają czasu dla córek. Albo żyją w luksusie i uważają, że drogie prezenty wynagrodzą dzieciom wszystko. Ale czy wyobrażasz sobie, że nagle masz szafę pełną nowych, markowych rzeczy, a twoi rodzice, rodzeństwo albo przyjaciółki nie pytają, skąd je wzięłaś - pytano w "Glamour»"14. Dorośli, mówiący swoim dzieciom, że najważniejszą wartością są pieniądze, wskazują im, że aby nie odstawać od rówieśników, należy zadbać o pozyskanie środków finansowych.

Rozpatrując kwestię sytuacji rodzinnej studentek, które nawiązały układ sponsorski można dojść do błędnego wniosku, że wychowywały się one w rodzinach patologicznych, lecz tak jest tylko w niewielkim procencie. Najczęściej wywodzą się zarówno z rodzin, w których były problemy finansowe, jak też z takich, gdzie rodzice zapewniali rodzinie dobry standard życia. Co zatem skłoniło je, aby podjąć się tego zajęcia? Najczęściej twierdzą, że chciały odciążyć finansowo rodziców i utrzymywać się samodzielnie. Dorośli - skoncentrowani na sobie, własnych problemach, zajęci spełnianiem własnych aspiracji zawodowych - zapominają o konieczności przekazywania wartości moralnych, okazywaniu miłości swoim dzieciom czy dążeniu do zrozumienia młodego pokolenia. Te zadania wielokrotnie przejmuje na siebie sponsor. Gdzie go zatem znajdują młode kobiety?

Obecnie to głównie Internet, oprócz metod bezpośrednich, ułatwia nawiązanie kontaktu - dyskretnie i anonimowo. Kilka lat temu ogłoszenia o sponsoringu (bez narażania się na usunięcie anonsu), można było zamieszczać w serwisach

12 B. Pietki e wi c z, Sponsorówki, „Polityka”, 10.01.2009, nr 2, s. 26-27.

13 Tamże.

${ }^{14}$ A. S z e w c z y k, K. Ko p o c z, Sponsoring - sprzedawanie swego ciała, „Glamour”, listopad 2010. 
erotycznych lub randkowych. Dziś istnieją specjalnie wydzielone sekcje z takimi ofertami, także w serwisach o charakterze typowo ogłoszeniowym. Istnieją nawet portale specjalizujące się w tej dziedzinie, jak np. szukamsponsora.pl. Poza Internetem, sponsora można znaleźć w gazetach z ogłoszeniem „dam pracę/szukam pracy” oraz poznać w kawiarni, w kinie czy na ulicy, tam, gdzie „wpadnie mu w oko” ładna dziewczyna z torbą wypchaną książkami albo teczką do noszenia rysunków.

Sponsoring jest pewnym rodzajem transakcji handlowej, niejednokrotnie spisywana jest umowa, dokładnie określająca zakres świadczeń każdej ze stron, czasami nawet na piśmie i w obecności świadków, tak jak przy zawieraniu umowy kupna - sprzedaży. Układ ze sponsorem jest z pozoru jasny: on płaci za seks, za czas jaki dziewczyna mu poświęca. W zamian za to oczekuje, że będzie dyskretna, dyspozycyjna i „na poziomie”, bo sponsorzy sami są wykształceni, inteligentni, robią kariery i nie potrzebują głupiutkiej panienki. Chcą kobiety, z którą mogą porozmawiać o polityce czy sztuce, która nie przyniesie im wstydu podczas wyjścia do teatru i nie skompromituje podczas kolacji z partnerami biznesowymi. Studentki dają taką gwarancję. Stąd właśnie popyt na nie ${ }^{15}$. Szacuje się, że „obrotne" spośród nich potrafią zarobić na sponsoringu 5 tysięcy złotych miesięcznie, a nawet więcej. Najbardziej zaskakuje, że te inteligentne, wykształcone, ambitne kobiety, które często studiują na dwóch kierunkach lub są już doktorantkami, uważają sponsoring za jeden z dopuszczalnych sposobów zarabiania na czesne za studia, podręczniki, wynajem mieszkania i drobne przyjemności. Seks to dla nich tylko środek do osiągnięcia celu. Nie chcą przyznać, że uprawiają go z czystego wyrachowania, że to jest najzwyczajniej w świecie złe i nie myślą o poważnych konsekwencjach, jakie niesie układ ze sponsorem ${ }^{16}$.

Funkcjonowanie w takim układzie niesie za sobą wiele zagrożeń dla obecnego i przyszłego życia tych osób. Marek Świętopełka-Zawadzki, psychiatra i specjalista terapii uzależnień pokazuje pułapki, jakie mogą czyhać na dziewczyny, które angażują się w tzw. „związki sponsorskie”. Do nich zalicza przede wszystkim budowanie nieprawidłowych relacji partnerskich. Mężczyźni i kobiety nie potrafią tworzyć pozytywnych relacji i pewnie ich wcześniejsze związki też pozostawiały wiele do życzenia. Być może ich rodzice funkcjonowali podobnie. Taki wybór może też wynikać z miłosnego zawodu, chęci uniknięcia go w przyszłości. Poza tym dziewczyny powinny liczyć się ze skutkami ubocznymi, kiedy wejdą w taki układ. Pomimo tego, że obie strony są zadowolone z niego, w rzeczywistości jest inaczej. Utrzymanka wpada w nerwicę, depresję, często pojawia się u niej autoagresja. Czuje, że więzi jakie łączą ją z mężczyzną są kruche, zdaje sobie sprawę, że w każdej chwili może ją zastąpić inną, chwilowo bardziej interesującą kobietą. Poza tym powinny wiedzieć, że ich przyszłość nie przedstawia się obiecująco. Pozorny brak konieczności liczenia się z uczuciami drugiej osoby i wygodne życie potrafią uzależnić. Wtedy potrzebna jest często pomoc ze strony psychologa, z której, prędzej czy później, większość dziewcząt korzysta ${ }^{17}$.

15 b.a., Seks na lunch, „Wprost”, 20.09.2009.

$16 \mathrm{http}: / / s p o t k a n i a p r z y k a w i e . p l / p s y c h o l o g i a / s z p r z e d a m-s w o j e-c i a l o-w i e c-s z u k a m-s p o n s o r a$ [data dostępu 25.02.2011].

17 Tamże. 
Koszty psychiczne są jednak tak duże, że do końca życia będą stanowiły rys na myśleniu i odczuwaniu takiej młodej dziewczyny. Już teraz pozbawia się ona wolności, gdyż staje się «poniekąd» własnością mężczyzny, który płaci za jej czas i jest niewolnicą pieniądza. W przyszłości pozbawia się szansy na uczciwą, prawdziwą miłość. Nawet jeśli pozna kogoś jedynego, przeszłość położy się cieniem na ich związku. Kobieta nie będzie sobą, nie opuści jej lęk, że partner dowie się o niechlubnej przeszłości ${ }^{18}$.

Sponsorowane studentki często pochodzą z tzw. dobrych domów, ale psychologowie są zgodni: te dziewczyny mają zaburzony system wartości, brakuje im zainteresowania ze strony rodziców, ich miłości. Chcą być w centrum uwagi, a sponsor daje im poczucie, że są wyjątkowe. Ogólnie nie pochodzą z rozbitej, patologicznej rodziny. Wydaje się, że takim dziewczynom nie jest łatwo, ale jednak nie rezygnują z tego zajęcia. Widocznie wolą żyć w ciągłym strachu, mając zapewniony odpowiednio wysoki standard materialny poprzez stałe zabezpieczenie finansowe ze strony sponsora, niż narażać się na niepewność w tym względzie z powodu braku pieniędzy.

Bycie utrzymanką to nie tylko życie w luksusie. Dziewczyny „pragną oderwać się od szarzyzny życia, przeżyć przygodę, a także znaleźć bogatego męża". Jednak w „umowie o dzieło”, którą zawiera dziewczyna ze sponsorem, wszelkie wyrywanie go ze związku jest z góry przez żonatego kandydata wykluczane. Seks ma być bez zobowiązań, z wyjątkiem finansowym. Zdarzają się jednak wyjątki i z czasem rozkwita między nimi uczucie. Niestety „takie małżeństwa szybko się rozpadają. Coś w nich rwie się i pęka. Może facet czuje, że żona wisi na nim obojętnie jak ozdoba na świątecznym świerku albo jak chciwy bluszcz"19.

W związku sponsorskim dziewczyna musi być w ciągłej gotowości, kiedy tylko potrzebuje ją sponsor. Najbardziej zaskakuje fakt, że na początku XXI w. potrafi się podporządkować temu po to, aby osiągnąć korzyść materialną. Teresa Sołtysiak z Uniwersytetu Kazimierza Wielkiego w Bydgoszczy bada zjawisko sponsoringu wśród kobiet. Większość z nich już po pierwszej propozycji sponsorowania była podekscytowana, zadowolona, czekała na kolejne spotkania, bo postrzegała je w kategoriach zysków, nie strat.

$Z$ reguły jest tak, że dziewczyny, decydując się na układ sponsorski, kierują się ciekawością albo rzeczywistą potrzebą finansową. Zakładają, że to będzie tylko raz, ale sponsoring jest jak narkotyk. Te, które doświadczyły go, mówią, że nie mogą przestać, zwłaszcza, że rezygnacja wiązałaby się z powrotem do życia na niższym poziomie. Możliwość studiowania, życie na przyzwoitym poziomie, bywanie w ekskluzywnych miejscach, poznawanie ważnych ludzi, wycieczki - takie korzyści wymieniają utrzymanki. W sponsorach widzą dżentelmenów, w ich towarzystwie czują się lepiej niż wśród rówieśników, są przez nich szanowane. Bywa, że i poniżane - zwłaszcza w trakcie perwersyjnych zbliżeń seksualnych. Jednak złe traktowanie przez mężczyzn nie jest powodem, dla którego zrywałyby związki. Tkwią w nich tak długo, aż zrezygnuje z nich sponsor, zastępując je kolejną studentką.

${ }^{18}$ K. Charkow sk a, Zjawisko prostytucji..., s. 31.

${ }^{19}$ B. Pietkiewicz, Sponsorówki, s. 27. 
Kobiety pytane o negatywne skutki bycia sponsorowaną wymieniają tylko dwa - oszukiwanie otoczenia oraz strach, że ktoś się dowie. A wstyd? Poczucie winy? Tylko jedna powiedziała, że czuje się jak prostytutka. Pozostałe nie widzą w sponsoringu nic złego. Przeciwnie - ,jest fajnie, szybko można zarobić, niezbyt się napracować. A to, że mężczyzna płaci? W normalnym związku też facet za wszystko płaci - mówiły podczas uniwersyteckich badań"20. Posiadanie sponsora nie jest tak moralnie obciążające, jak prostytuowanie się. Można to sobie jakoś wytłumaczyć. „On jest jedyny, podoba mi się, nie robię nic złego, on mi kupuje te wszystkie rzeczy, bo mnie lubi". Poza tym, sponsoring to nie tylko seks, ale również rozrywka, poznawanie kultury, wspólne spędzanie czasu, być może nawet intymne rozmowy - w tych warunkach rolę zaczynają też grać emocje, więc łatwo usprawiedliwiać taką sytuację, bo przecież nic na świecie nie jest czarno-białe". Jedna z dziewczyn opowiadała, że sponsor na głowie stawał, żeby jej kupić jakiś trudny do dostania podręcznik, lecz w końcu nabył i wręczył. Jest to według niektórych inwestowanie w swoją karierę, nawiązanie dobrych kontaktów w branży medialnej.

Dziewczyny wchodzące w układ sponsorski uważają, że to prosta wymiana: seks za pieniądze. Tymczasem prowadzi on do konsekwencji o wymiarze psychicznym i emocjonalnym. Przez 24 godziny na dobę muszą być do dyspozycji sponsora, nie mogą budować trwałych, bliskich związków z innymi - zwykle nie mają one przyjaciół, którym mogłyby się zwierzać ze swoich problemów.

$Z$ tego zajęcia niezwykle trudno odejść, ale niektórym się udaje. Po zakończeniu studiów zaczynają pracować w wyuczonym zawodzie, zakochują się, zakładają rodziny, a miniony czas starają się wymazać z pamięci. Jednak jest on nie do wymazania i płaci się za niego wysoką cenę, chociaż jest ona odroczona w czasie. Nawet gdy założą rodziny, nadal będą miały transakcyjne podejście do życia - to jest to niebezpieczeństwo. Do momentu, w którym była sponsorówka nie przejdzie terapii, nie ma szans na budowanie szczęśliwego związku i dobrego wychowywania dzieci. Istnieje również ryzyko, że za każdym razem, kiedy będzie miała kłopoty finansowe, wróci do prostytucji. Im dłużej prowadziła podwójne życie, tym więcej odczuwać będzie lęków wynikających z permanentnego ukrywania się. Te z kolei skutkują nieumiejętnością ustabilizowania sobie życia ${ }^{21}$.

Czy sponsoring wśród polskich studentek stał się standardem? Młode kobiety do prostytuowania się popychają zazwyczaj zbyt wygórowane oczekiwania od życia, tj. chęć otaczania się pięknymi drobiazgami, noszenia w drogiej torebce kluczyków do wymarzonego samochodu i trzymania w łazience kosmetyków z górnej półki. Wielokrotnie jest to silniejsze niż wpajane przez rodziców zasa$\mathrm{dy}^{22}$. Sponsoring, wbrew pozorom, nie jest łatwym zajęciem. To zjawisko niebez-

${ }^{20} \mathrm{http}: / /$ religiapokoju.blox.pl/2009/03/Sponsoring-prostytucja-gimnazjalistek-licealistek.html [data dostępu marzec 2009].

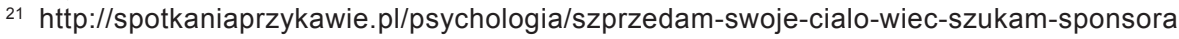
[data dostępu: 25.02.2011].

${ }^{22}$ http://www.papilot.pl/zycie/2915/Prostytucja-zrodlo-dochodu-polskich-studentek.html [data dostępu: 15.05.2011]. 
pieczne i wykańczające psychicznie. Psychologowie wyjaśniają, że to brak uczuć wyższych skłania młode osoby do jego podjęcia. Osoby takie mogą wykazywać niedojrzałość emocjonalną w tych obszarach emocjonalnych, które odpowiadają za poczucie winy czy sumienie ${ }^{23}$.

Analizując zawartość artykułów w czasopiśmiennictwie, a także literaturę przedmiotu, trzeba przyznać, że wyjątkowym pesymizmem napawa funkcjonowanie w sponsorskich związkach partnerskich najczęściej studentek kierunków humanistycznych, w tym bardzo często pedagogiki. A przecież szczególnie one doskonale powinny zdawać sobie sprawę z zagrożeń, jakie taki układ ze sobą niesie, zarówno wobec nich samych, jak i ich przyszłości. Czy zatem zbyt rzadko na zajęciach uniwersyteckich uwrażliwia się młode osoby na zagrożenia związane z konsumpcyjnym stylem życia? Czy nie należy więcej miejsca przeznaczać na wskazywanie alternatywnych form funkcjonowania we współczesnym społeczeństwie, w którym nie tylko kwestie materialne powinny być traktowane priorytetowo? Są to pytania, na które w gronie pedagogów musimy sami znaleźć odpowiedź, jeśli będziemy dążyć do zmiany tej sytuacji wśród naszych podopiecznych.

${ }^{23}$ M. G le ń, Studentka szuka..., s. 14. 